\title{
Cantharidin Inhibits the Growth of Triple-Negative Breast Cancer Cells by Suppressing Autophagy and Inducing Apoptosis in Vitro and in Vivo
}

\author{
Hong-chang Lia Zhi-hua Xia ${ }^{\mathrm{a}}$ Ya-feng Chen ${ }^{\mathrm{a}}$ Fan Yang ${ }^{\mathrm{a}}$ Wen Feng ${ }^{\mathrm{a}}$ Han Cai ${ }^{\mathrm{a}}$ \\ Yi Mei $^{\mathrm{a}} \quad \mathrm{Yi}_{\mathrm{i}}$-ming Jiang ${ }^{\mathrm{a}} \mathrm{Ke} \mathrm{Xu}^{\mathrm{b}}$ Dian-xu Feng ${ }^{\mathrm{a}}$
}

aDepartment of General Surgery, Putuo Hospital, Shanghai University of Traditional Chinese Medicine, Shanghai, ${ }^{b}$ Central Laboratory of Putuo Hospital and Interventional Cancer Institute of Chinese Integrative Medicine, Shanghai University of Traditional Chinese Medicine, Shanghai, China

\section{Key Words}

Cantharidin • Apoptosis • Autophagy • Triple-negative breast cancer

\begin{abstract}
Background/Aims: Cantharidin, a type of terpenoid secreted by the blister beetle Mylabris phalerata (Pallas), has attracted great attention in cancer therapy because of its potential anti-cancer activities. Here, we report the effects on apoptosis and autophagy in human triple-negative breast cancer (TNBC) cell lines after treatment with cantharidin and attempt to elucidate the underlying mechanisms. Methods: MDA-MB-231 and MDA-MB-468 cells were treated with cantharidin and cell proliferation was examined using CCK-8 and clone formation assays. The expression of apoptosis- and autophagy-associated proteins was detected by western blotting. Cells were infected with lentivirus carrying the Beclin-1 gene, and MDA-MB-231-beclin1 (MB231-Bec) and MDA-MB-468-beclin-1(MB468-Bec) cells stably expressing Beclin-1 were established. Autophagic vacuoles in cells were observed with LC3 staining using fluorescence microscopy, and apoptotic cells were detected via flow cytometry. Tumor growth was assessed by subcutaneous inoculation of TNBC cells into BALB/c nude mice. Results: Cantharidin inhibited the proliferation of MDA-MB-231 and MDA-MB-468 cells, and induced cell apoptosis. Cantharidin additionally inhibited the conversion of LC3 I to LC3 II and autophagosome formation by suppressing the expression of Beclin-1. Furthermore, overexpression of Beclin-1 in TNBC cells attenuated the cytotoxicity of cantharidin. In vivo, cantharidin inhibited the growth of MDA-MB-231 and MDA-MB-468 xenografts in nude mice by suppressing autophagy and inducing apoptosis, and Beclin-1 overexpression in TNBC cells reduced the efficacy of cantharidin. Conclusions: Cantharidin inhibits autophagy by

H. Li and Z. Xia contributed equally to this work.

Dian-xu Feng and $\mathrm{Ke} \mathrm{Xu}$

KARGER

Department of General Surgery, Putuo Hospital, Shanghai University of Traditional Chinese Medicine, and Central Laboratory of Putuo Hospital and Interventional Cancer Institute of Chinese Integrative Medicine,Shanghai, (China)

E-Mail abctougaoyouxiang@163.com, cola519@163.com
\end{abstract}




\section{Cellular Physiology Cell Physiol Biochem 2017;43:1829-1840 \begin{tabular}{ll|l} 
and Biochemistry Published online: October 19, 2017 & $\begin{array}{l}\text { (c) } 2017 \text { The Author(s). Published by S. Karger AG, Basel } \\
\text { www.karger.com/cpb }\end{array}$ \\
\hline
\end{tabular} \\ Li et al.: Cantharidin Inhibits the Growth of TNBC Cells}

suppressing Beclin-1 expression and inducing apoptosis of TNBC cells in vitro and in vivo, thereby representing a potential strategy for the treatment of TNBC.

\section{Introduction}

Breast cancer is the most frequently diagnosed cancer and the leading cause of mortality among females, accounting for $23 \%$ of the total cancer cases and $14 \%$ of cancerrelated deaths, according to the global cancer statistics for 2011[1]. Cancers of the breast are classified into five distinct types based on molecular heterogeneity and gene expression: two ER (estrogen receptor)-positive luminal subtypes, HER2 (human epidermal growth factor receptor type 2)-overexpression subgroup, a normal breast gene expression subgroup, and a basal-like subgroup. The basal-like subgroup is characterized by the expression of basal-cell cytokeratins 5/6 and 17 and an absence or low levels of ER and HER2 expression [2]. TNBC (triple-negative breast cancer) was first defined in 2005[3] as comprising tumors lacking expression of ER, PgR (progesterone receptor), and HER2. TNBC accounts for approximately $15 \%$ of all types of breast cancer [4]. Early diagnosis of breast cancer significantly improves 5 -year survival rates. There are studies focusing on identification of novel biomarkers such as glycoprotein for use in TNBC detection [3].Still patients with TNBC exhibit relatively poor outcomes, and specific treatment guidelines are not available for this type of cancer. Moreover, these patients are resistant to existing endocrine therapies and HER2-targeted therapies, such as trastuzumab, as a result of specific molecular expression features of TNBC[5]. Therefore, targeted therapeutics is urgently needed.

Cantharidin, a type of terpenoid obtained from the blister beetle (Mylabris phalerata Pall. and Mylabris cichorii Linn.), is used as a traditional Chinese medicine with anticancer, antibiotic, antiviral, and immune-regulating activities [6, 7]. Recent studies have shown that cantharidin and its derivatives exert cytotoxic effects against cancer cells. In addition, these compounds have been shown to effectively inhibit cell proliferation in numerous cancer cell lines such as leukemic cells [8,9]_ENREF_7, as well as in bladder [10,11]_ENREF_8, colorectal [12], pancreatic [13], hepatic [14,15]_ENREF_11, oral [16], and breast cancers [17, 18]_ENREF_16. Previous studies have reported that cantharidin and its derivatives exhibit strong antitumor activity through cell growth inhibition and cell apoptosis induction in vitro and in vivo. Furthermore, the cytotoxicity of these compounds was found to be independent of estrogen, progesterone and epidermal growth factor receptors. Cantharidin is therefore considered a highly promising candidate agent for treatment of TNBC.

The various types of PCD (programmed cell death), apoptosis, and autophagy are highly regulated by both the extrinsic death receptor (DR) pathway and intrinsic mitochondrial pathway [19]. Apoptosis ultimately leads to cell death, whereas autophagy plays either pro-survival or pro-death roles [20]. Bax belongs to the pro-apoptotic Bcl-2 family and Bcl-2 belongs to the anti-apoptotic Bcl-2 family [21-23]_ENREF_21. Activation of PARP and caspase-3 triggers downstream pathways, resulting in apoptosis and cell death [24-27] ENREF_22_ENREF_22. The Beclin-1 pathway plays a role in pro-tumor autophagy $[28,29]$, and LC3 participates in autophagosome formation [30]. The interplay between apoptosis and autophagy is complex and poorly understood. In this study, we treated TNBC cells with cantharidin and detected cell apoptosis and autophagy after treatment to clarify the cytotoxicity in TNBC cells induced by cantharidin.

In the present study, cantharidin was firstly demonstrated to exert anti-tumor effects in human MDA-MB-231 and MDA-MB-468 triple-negative breast cancer cells by inducing apoptosis and inhibiting pro-survival autophagy by suppressing Beclin-1 expression both in vitro and in vivo. The present study strongly indicates that cantharidin represents a novel treatment agent and represents a potential strategy for the treatment of TNBC. 


\section{Cellular Physiology Cell Physiol Biochem 2017;43:1829-1840 \begin{tabular}{ll|l} 
and Biochemistry Published online: October 19, 2017 & $\begin{array}{l}\text { (c) } 2017 \text { The Author(s). Published by S. Karger AG, Basel } \\
\text { www.karger.com/cpb }\end{array}$ \\
\hline
\end{tabular}}

Li et al.: Cantharidin Inhibits the Growth of TNBC Cells

\section{Materials and Methods}

\section{Reagents}

Cantharidin was purchased from Sigma. Propidium iodide (PI) and DAPI (dihydrochloride) were purchased from Thermo Fisher Scientific. PARP, cleaved PARP, caspase 3, cleaved caspase 3, Bax, Bcl-2, LC3B I, LC3B II, p62, Beclin-1, and GAPDH antibodies were purchased from Cell Signaling Technology (MA, USA)

\section{Cell lines and cell culture}

The human MDA-MB-231 and MDA-MB-468 breast cancer cell lines were purchased from the American Type Culture Collection (ATCC). Cells were maintained in Dulbecco's modified Eagle's medium (DMEM) supplemented with $10 \%$ fetal bovine serum (FBS), streptomycin $(100 \mathrm{U} / \mathrm{mL})$, and penicillin $(100 \mathrm{U} / \mathrm{mL})$ at $37^{\circ} \mathrm{C}$ in a humidified incubator with $5 \% \mathrm{CO}_{2}$.

Beclin-1 overexpressing cell line establishment

Lentivirus carrying Beclin-1 gene were produced by Shanghai Genechem Company. MDA-MB-231 and MDA-MB-468 cells were inoculated in 12-well plate and incubated with complete medium with lentivirus. $24 \mathrm{~h}$ after seeding, medium contained were aspirated and replaced with $1 \mathrm{ml}$ fresh medium. In order to obtain a stable Beclin-1 overexpressing cell line, the lentivirus infected cells were screened by the culture medium containing $2 \mathrm{ug} / \mathrm{ml}$ of puromycin for 2 weeks.

\section{CCK-8 assay}

The CCK-8 assay was used to determine cell viability following treatment with cantharidin. MDAMB-231 and MDA-MB-468 cells were seeded at a density of 2, 000 cells/well in 96-well plates and treated with cantharidin for $72 \mathrm{~h}$. Cell viability was assessed using Cell Counting Kit-8 (CCK-8) (Dojindo) according to the manufacturer's instructions.

\section{Colony formation assay}

MDA-MB-231 and MDA-MB-468 cells were plated into a 6-well plate at a concentration of 500 cells/ well and treated with 0,1 , and $5 \mu \mathrm{g} / \mathrm{ml}$ cantharidin. Colony formation after 10 days of culture was examined by staining with crystal violet at room temperature for $20 \mathrm{~min}$.

\section{Flow cytometric analysis of apoptosis}

Annexin V-FITC Apoptosis Detection Kit (BD) was used to evaluate the percentage of apoptotic cells. MDA-MB-231 and MDA-MB-468 cells were treated with 0,1 , and $5 \mu \mathrm{g} / \mathrm{ml}$ cantharidin for $48 \mathrm{~h}$. Then, $5 \times 10^{5}$ treated cells were centrifuged and re-suspended in cold $1 \times$ binding buffer, after which $1.25 \mu$ l of Annexin V-FITC and $10 \mu \mathrm{l}$ of propidium iodide (PI) were added and the suspension was analyzed by flow cytometry (FACScan).

\section{Immunofluorescence analysis of autophagy}

MDA-MB-231 and MDA-MB-468 cells were plated on glass-bottom cell culture dishes (Nest) at 50\% confluency and then treated with 0,1 , and $5 \mu \mathrm{g} / \mathrm{ml}$ cantharidin for $48 \mathrm{~h}$. The prepared cells were washed in PBS, fixed in 4\% paraformaldehyde (PFA) at room temperature for $15 \mathrm{~min}$, permeabilized in $0.2 \%$ Triton X-100 for $15 \mathrm{~min}$, and blocked with 1\% bovine serum albumin (BSA) in PBS for $1 \mathrm{~h}$. Then, the cells were stained with the primary LC3 antibody at $4^{\circ} \mathrm{C}$ overnight and incubated with an Alexa 488-conjugated donkey anti-mouse secondary antibody (Jackson ImmunoResearch) at $37^{\circ} \mathrm{C}$ for $1 \mathrm{~h}$.

\section{Immunoblotting}

Treated cells were collected and suspended in mammalian protein extraction reagent (Thermo) for at least $30 \mathrm{~min}$ on ice. Cell lysates were clarified by centrifugation at $12,000 \times \mathrm{g}$ for $10 \mathrm{~min}$ at $4^{\circ} \mathrm{C}$, and the supernatants were mixed with $5 \times$ loading dye and boiled for $10 \mathrm{~min}$. The protein content in the supernatant was measured using a Bio-Rad DC protein assay kit II (Bio-Rad). Proteins were separated by electrophoresis on a $10 \%$ sodium dodecyl sulfate polyacrylamide gel and electrotransferred onto a PVDF membrane. The membrane was blocked in 5\% nonfat skim milk and probed with primary antibodies for PARP, cleaved PARP, caspase 3, cleaved caspase 3, Bax, Bcl-2, LC3B I, LC3B II, p62, Beclin-1, and GAPDH; this was followed by 
incubation with horseradish peroxidase-conjugated secondary antibodies. Protein expression was detected using an enhanced chemiluminescence system (Amersham Pharmacia).

\section{Xenograft mouse models}

All animal experiments were approved and conducted by the Institutional Animal Care and Use Committee. BALB/c nude mice (4-6 weeks-old) were subcutaneously injected with Beclin-1-overexpressing cells and their parent TNBC MDA-MB-231 and MDA-MB-468 cells, followed by treatment with cantharidin or vehicle. Mice were treated with either $10 \mathrm{mg} / \mathrm{kg}$ cantharidin or the vehicle through intravenous injection every 2 days. Tumor volumes were measured every three days until mice were sacrificed 3 weeks later.

\section{TUNEL assay}

TdT-mediated dUTP nick end-labeling assay (TUNEL) reaction mixture (Roche) was used to detect apoptotic xenograft tumor cells. After incubation with the reaction mixture, samples were analyzed by comparing relative fluorescence units.

\section{Statistical analysis}

All statistical analyses were performed using SPSS 14.0 software. Values are presented as the ratio \pm SD of the control. Student's t-test and one-way ANOVA were used to analyze statistical significance. $p<0.05$ was considered to indicate statistical significance. Each experiment was performed in triplicate.

\section{Results}

\section{Growth was inhibited by cantharidin in human TNBC cells}

It has been reported that cantharidin inhibits cancer cell proliferation. To evaluate the cytotoxicity of cantharidin against TNBC cells, MDA-MB-231 and MDA-MB-468 cells were treated with a cantharidin gradient for 48 h. As shown in Fig. 1 A and B, cell viability decreased following treatment with cantharidin in a concentration-dependent manner.

Fig. 1. Proliferation inhibition by cantharidin in TNBC cells. (A) Triple-negative breast cancer MDA-MB-231 and MDA-MB-468 cells were treated with $10^{-1}$, $10^{0}, 10^{1}, 10^{2}, 10^{3}$, and $10^{4} \mu \mathrm{g} / \mathrm{ml}$ cantharidin for $48 \mathrm{~h}$. Then, cell viability was determined using a CCK-8 assay. The results are the mean \pm SD of independent experiments performed in triplicate. (B) MDA-MB-231 and MDA-MB-468 cells were seeded on the plates and treated with 0,1 , and $5 \mu \mathrm{g} / \mathrm{ml}$ cantharidin. Colony formation was assessed by crystal violet staining after 10 days of culture. The results are the mean \pm SD of independent experiments performed in triplicate. $\mathrm{P}<0.05$ was considered statistically significant, ${ }^{*} \mathrm{P}<0.05$, ** $\mathrm{P}<0.01$, *** $\mathrm{P}<0.001$ versus the control.

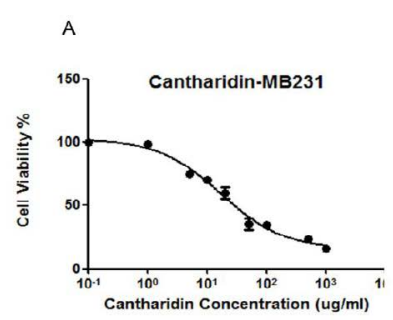

B

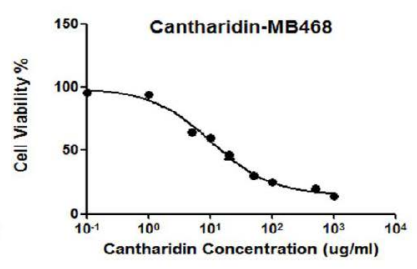

c
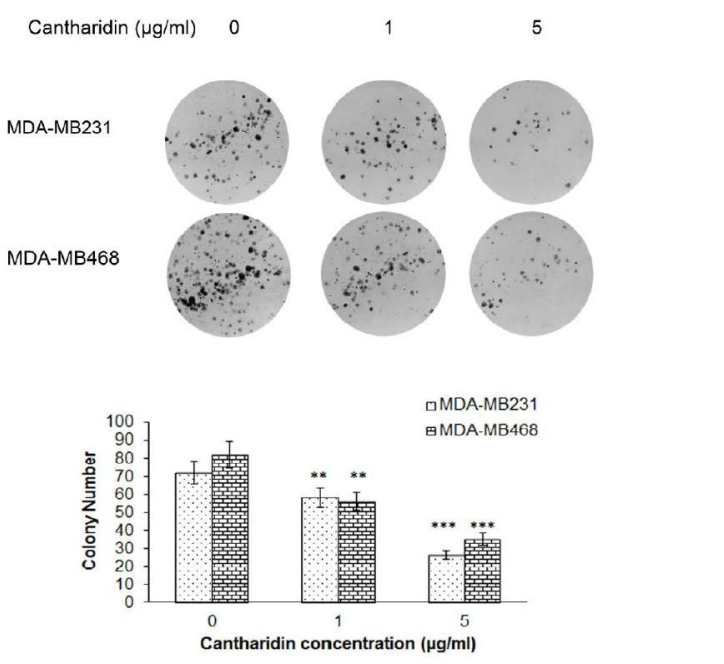
In addition, the colony formation assay suggested that the number of developed colonies generated from cantharidin-treated MDA-MB-231 and MDA-MB-468 cells was lower than that among control cells (Fig. $1 \mathrm{C}$ ). It was concluded that cantharidin inhibits the growth of MDA-MB-231 and MDA-MB-468 cells in a concentration-dependent manner.

\section{Apoptosis was induced by cantharidin in human TNBC cells}

To determine whether cantharidin-induced cytotoxicity resulted from the induction of apoptotic cell death, we investigated the level of apoptosis in TNBC cells following treatment with cantharidin by flow cytometry with Annexin V and PI staining. As shown in Fig. 2A, the apoptotic index was significantly elevated in TNBC cells treated with cantharidin. We then examined the expression of apoptosis-associated proteins in MDA-MB-231 and MDA-

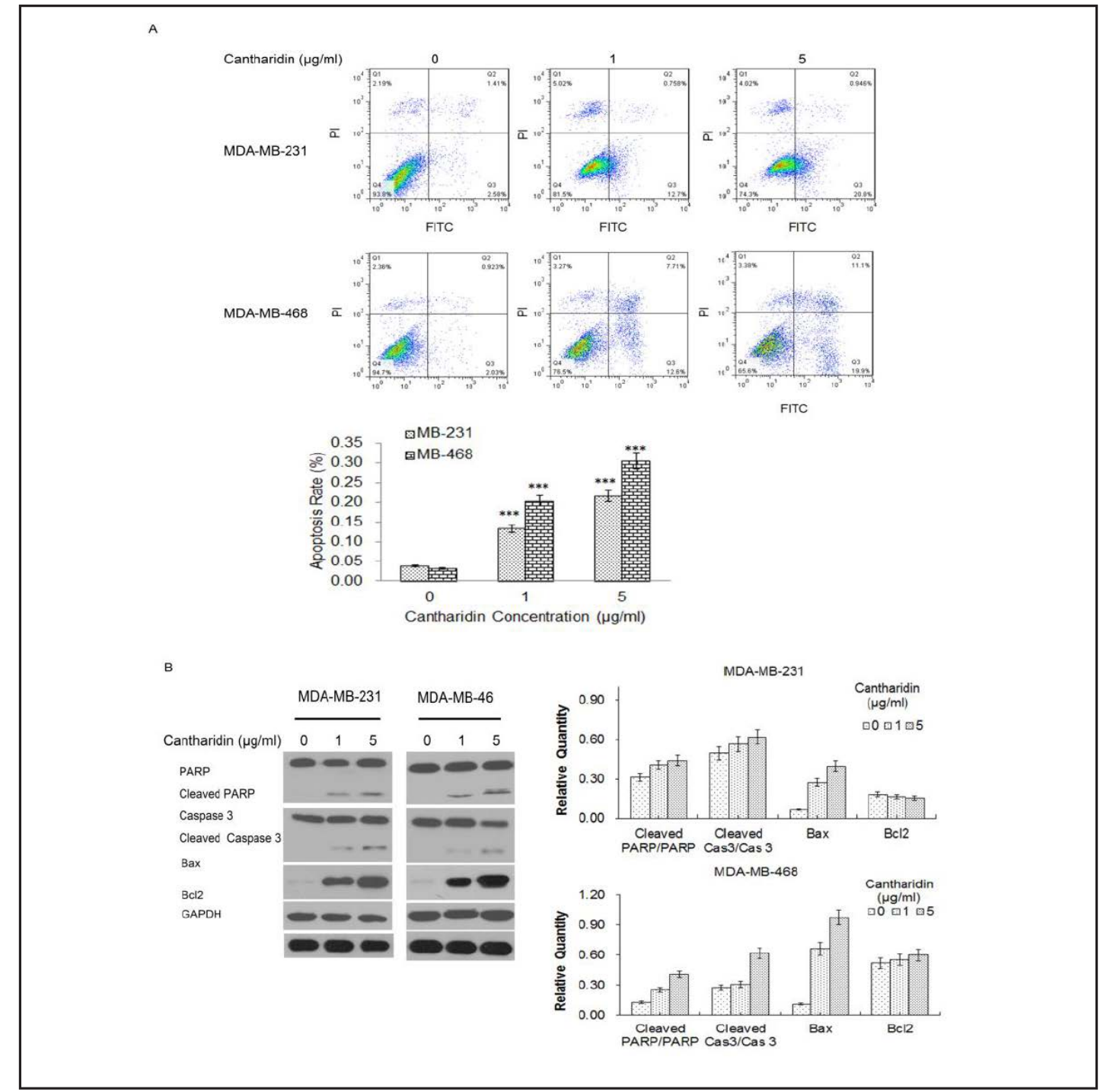

Fig. 2. Induction of apoptosis by cantharidin in TNBC cells. (A) MDA-MB-231 and MDA-MB-468 cells were treated with 0,1 , and $5 \mu \mathrm{g} / \mathrm{ml}$ cantharidin for $48 \mathrm{~h}$. Annexin V-FITC assay was performed to determine the apoptotic index of cells treated with cantharidin at various concentrations; the results were analyzed by flow cytometry. (B) Proteins expressed by treated TNBC cells were examined by immunoblotting. Apoptosisassociated proteins (active PARP, active caspase 3, Bax and $\mathrm{Bcl}$ 2) were detected using the corresponding antibodies with GAPDH as the control. The results are the mean \pm SD of independent experiments performed in triplicate. $\mathrm{P}<0.05$ was considered statistically significant, ${ }^{*} \mathrm{P}<0.05,{ }^{* *} \mathrm{P}<0.01,{ }^{* * *} \mathrm{P}<0.001$ versus the control.

\section{KARGER}




\section{Cellular Physiology Cell Physiol Biochem 2017;43:1829-1840 and Biochemistry \begin{tabular}{l|l} 
DOI: 10.1159/000484069 \\
Published online: October 19, 2017
\end{tabular} $\begin{aligned} & \text { O } 2017 \text { The Author(s). Published by S. Karger AG, Basel } \\
& \text { www.karger.com/cpb }\end{aligned}$ \\ Li et al.: Cantharidin Inhibits the Growth of TNBC Cells}

MB-468 cells. As shown in Fig. 2B, cantharidin treatment increased the expression of Bax, cleaved Caspase-3, and PARP, but had no effect on the expression of Bcl-2. Taken together, these findings show that cantharidin induces apoptosis of MDA-MB-231 and MDA-MB-468 cells.

\section{Autophagy was inhibited by cantharidin in human TNBC cells}

Furthermore, we explored whether cantharidin affects TNBC cell autophagy. Autophagy in MDA-MB-231 and MDA-MB-468 cells was detected via testing LC3 puncta by immunofluorescence staining with an LC3 antibody and the conversion of LC3 I to LC3 II by western blot, which are both classic indices for autophagy detection. Cantharidin treatment resulted in significant autophagy inhibition, as evidenced by a decrease in LC3 puncta (autophagosomes) (Fig. 3A). Consistently, western blot data showed that cantharidin decreased the conversion of LC3-I into LC3-II in MDA-MB-231 and MDA-MB-468 cells (Fig. 3B). Western blot results suggested that the expression of Beclin-1, a vital autophagyinduced protein, decreased after cantharidin treatment. Taken together, the data show that cantharidin inhibits autophagy in human TNBC cells by inhibiting expression of Beclin-1.

\section{Beclin-1 overexpression attenuated the cytotoxicity of cantharidin in vitro}

MDA-MB-231 and MDA-MB-468 cells were infected by lentivirus carrying the Beclin-1 gene, and MDA-MB-231-Beclin-1 (MB231-Bec) and MDA-MB-468-Beclin-1 (MB468-Bec)

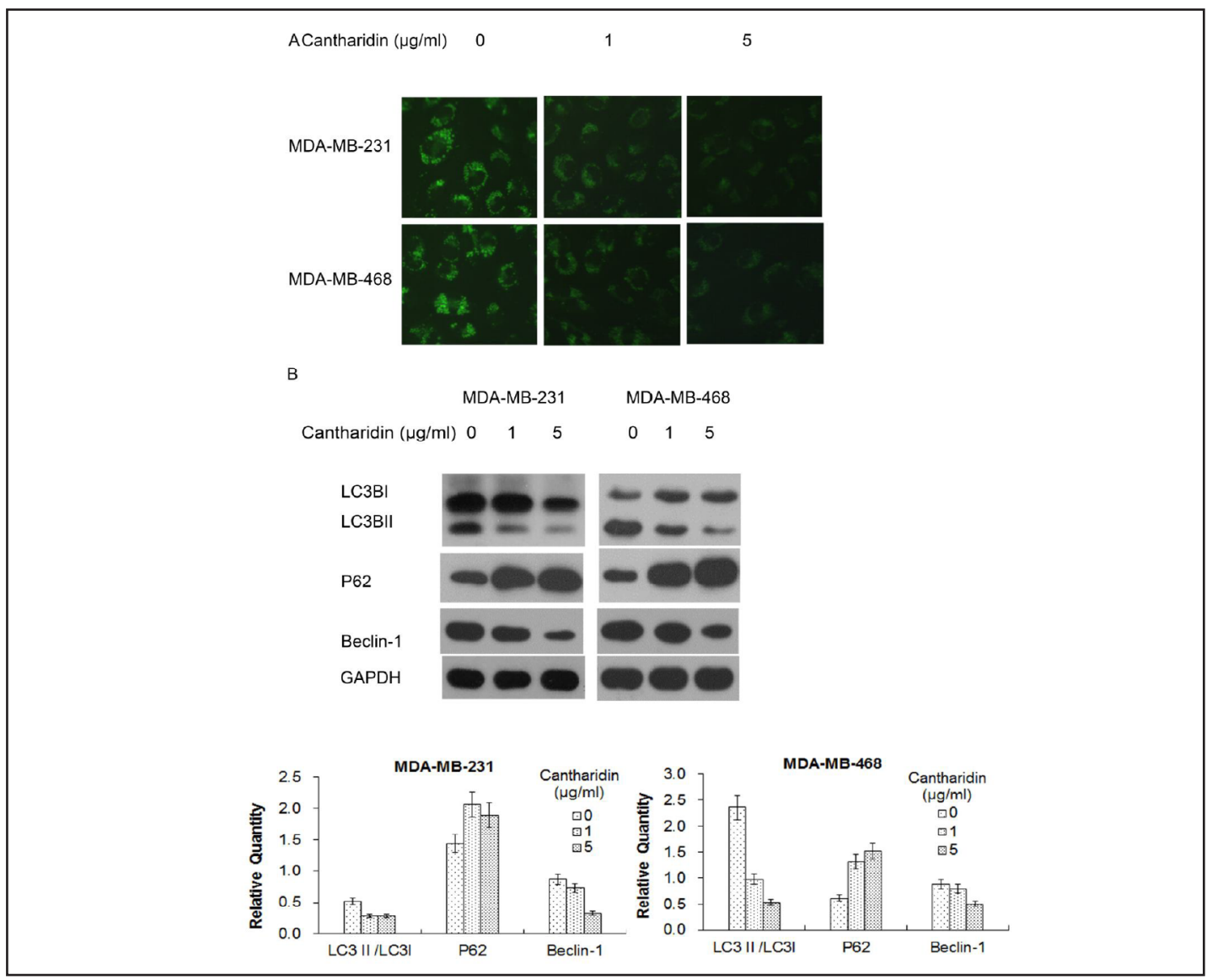

Fig. 3. Inhibition of autophagy in TNBC cells by cantharidin. (A) MDA-MB-231 and MDA-MB-468 cells were seeded on plates and treated with 0,1 , and $5 \mu \mathrm{g} / \mathrm{ml}$ cantharidin for $48 \mathrm{~h}$. Autophagosome formation was determined using immunofluorescence with an LC3 antibody. (B) Proteins expressed by treated TNBC cells were examined by immunoblotting. Autophagy-associated proteins (LC3 II, p62, and Beclin-1) were detected using the corresponding antibodies with GAPDH as the control. 


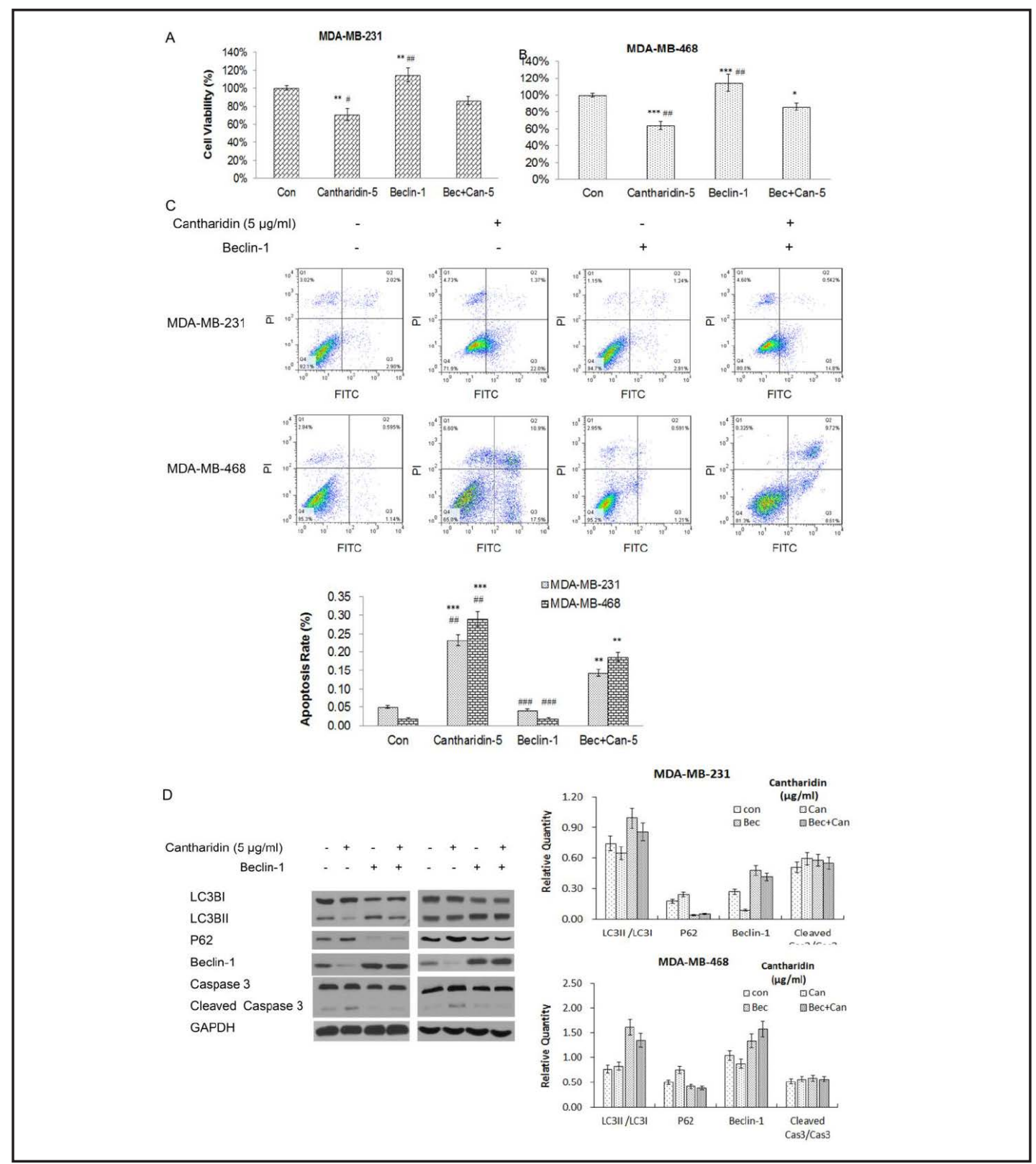

Fig. 4. Pro-survival autophagy in cantharidin-treated TNBC cells, Beclin-1-overexpressing cells, and their parent TNBC MDA-MB-231 and MDA-MB-468 cells. Cells were treated with cantharidin at $5 \mu \mathrm{g} / \mathrm{ml}$ for $48 \mathrm{~h}$. (A, B) Cell viability was then determined using the CCK-8 assay. (C) Annexin V-FITC assay was performed to examine Beclin-1 expression and the apoptotic index of cells following various treatments. Results were analyzed by flow cytometry. (D) Proteins expressed by cells were examined by immunoblotting. Autophagyassociated proteins (LC3 II, p62, and Beclin-1) and an apoptosis-associated protein (active caspase 3) were detected using the corresponding antibodies with GAPDH as the control. The results are the mean \pm SD of independent experiments performed in triplicate. $\mathrm{P}<0.05$ was considered statistically significant, ${ }^{*} \mathrm{P}<0.05$, ** $\mathrm{P}<0.01$, *** $\mathrm{P}<0.001$ versus the control, \# $\mathrm{P}<0.05$, \#\# $\mathrm{P}<0.01$, \#\#\# $\mathrm{P}<0.001$ versus cantharidin in Beclin- 1 overexpressing cells.

cells stably expressing Beclin-1 were established. The cells stably expressing Beclin-1 and their parent cells were treated with cantharidin at $5 \mu \mathrm{g} / \mathrm{ml}$ for $48 \mathrm{~h}$, and cell viability was analyzed. As shown in Fig. 4A and 4B, Beclin-1 expression promoted TNBC cell proliferation. 


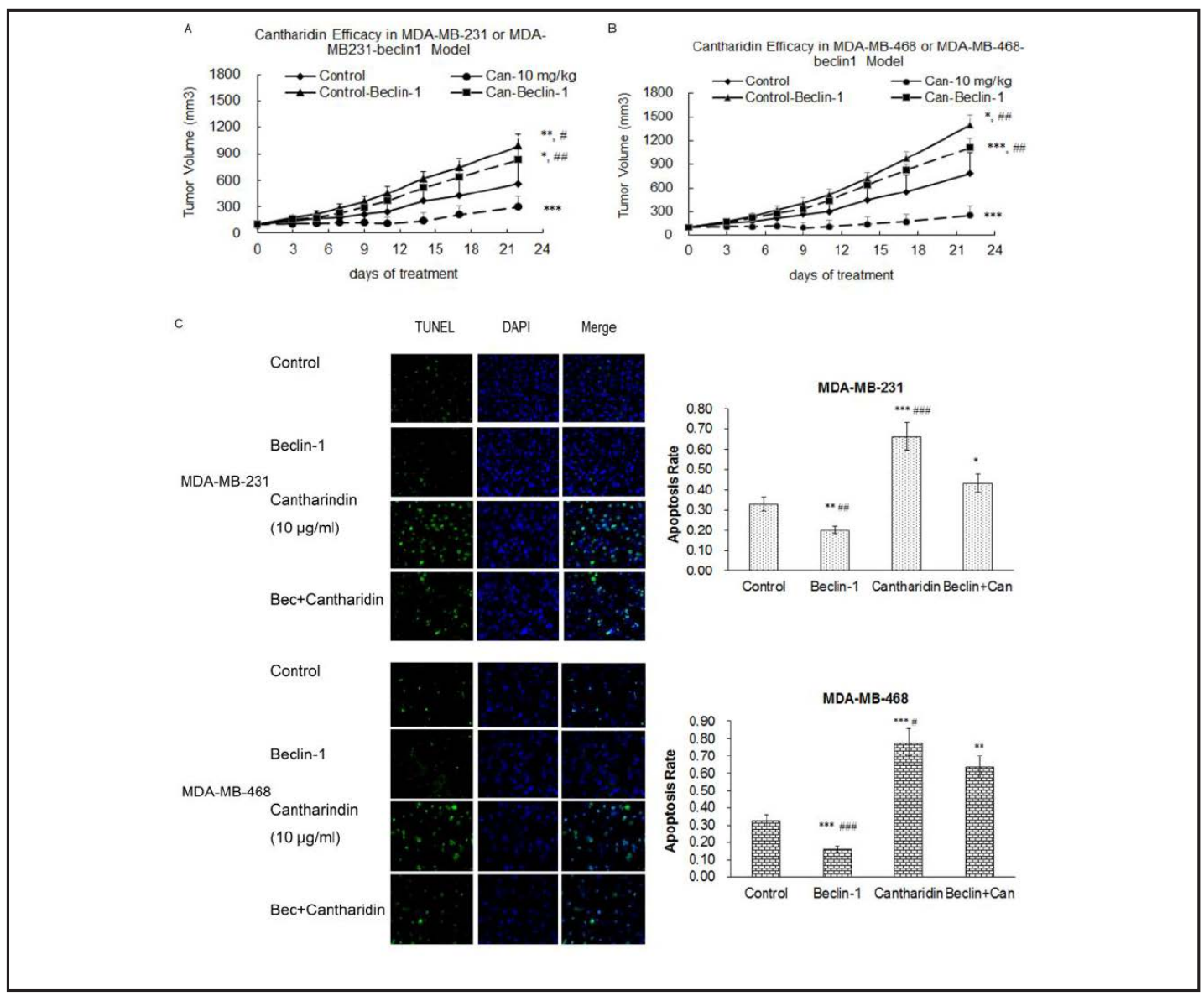

Fig. 5. Effects of cantharidin and putative underlying mechanisms in BALB/c nude mice. (A, B) Beclin1-overexpressing cells and their parent TNBC MDA-MB-231 and MDA-MB-468 cells were subcutaneously injected into the right flanks of nude mice in each group, and tumor volume was measured every three days. Mice were either treated with $10 \mathrm{mg} / \mathrm{kg}$ cantharidin or with control vehicle through intravenous injection every 2 days. (C, D) After the mice were sacrificed, cell apoptosis of each xenograft was determined by TUNEL assay. Green fluorescence represents apoptotic cell and blue fluorescence indicates cell nuclei. $\mathrm{P}$ $<0.05$ was considered statistically significant, ${ }^{*} \mathrm{P}<0.05$, ${ }^{* *} \mathrm{P}<0.01,{ }^{* * *} \mathrm{P}<0.001$ versus the control, \# $\mathrm{P}<0.05$, \#\# $\mathrm{P}<0.01$, \#\#\# $\mathrm{P}<0.001$ versus cantharidin in Beclin-1 overexpressing tumors.

In addition, the inhibition of cell growth by cantharidin was attenuated in Beclin-1overexpressing cells. Furthermore, FACS results suggested that the rate of apoptosis decreased in Beclin-1 overexpressing cells (Fig. 4C). Western blot results were similar to the FACS results (Fig. 4D). Taken together, the data show that Beclin-1 overexpression attenuated the cytotoxicity of cantharidin in vitro.

Cantharidin inhibited the growth of TNBC xenografts in nude mice by inhibiting autophagy and inducing apoptosis in vivo.

To examine the effect of cantharidin in vivo, nude mice bearing MDA-MB-231 and MDAMB-468 tumor xenografts and Beclin-1 overexpressing tumors were treated with vehicle and cantharidin at a dose of $10 \mathrm{mg} / \mathrm{kg}$ through intravenous injection every 2 days. Tumor volume was measured every 3 days and tumor weight was measured at the end of the study (Fig. 5A, 5B). The data suggest that cantharidin inhibited the growth of TNBC xenografts in nude mice, and that Beclin-1 overexpression in cells reduced the efficacy of cantharidin. TUNEL staining demonstrated a significant increase in apoptotic cells in the cantharidin- 


\section{Cellular Physiology Cell Physiol Biochem 2017;43:1829-1840 \\ \begin{tabular}{ll|l} 
and Biochemistry Published online: October 19, 2017 & $\begin{array}{l}\text { (c) } 2017 \text { The Author(s). Published by S. Karger AG, Basel } \\
\text { www.karger.com/cpb }\end{array}$ \\
\hline
\end{tabular} \\ Li et al.: Cantharidin Inhibits the Growth of TNBC Cells}

treated group, and indicated decreased apoptosis in Beclin-1 overexpressing cells (Fig. 5C, 5D). Together, these data show that cantharidin inhibited the growth of TNBC xenografts in nude mice by inhibiting autophagy and inducing apoptosis in vivo.

\section{Discussion}

Cantharidin is reported to exert cytotoxic effects against various kinds of cancer cells, including breast cancers. In this study, cantharidin was shown to exert strong cytotoxicity against human MDA-MB-231 and MDA-MB-468 triple-negative breast cancer cells, inhibiting cell proliferation in vitro or in vivo by inducing apoptosis and inhibiting autophagy. Moreover, our results showed that cantharidin inhibited both the conversion of LC3 I to LC3 II and autophagosome formation by suppressing the expression of Beclin-1. However, Beclin-1 overexpression was found to attenuate the cytotoxicity of cantharidin, which suggests that cantharidin may inhibit pro-survival autophagy to attenuate TNBC cell proliferation. The in vivo assay also showed that cantharidin inhibited the growth of TNBC xenografts by suppressing autophagy and inducing apoptosis, and that Beclin-1 overexpression in TNBC cells decreased the efficacy of cantharidin. Therefore, cantharidin induced TNBC cell apoptosis and inhibited pro-survival autophagy by suppressing Beclin-1 both in vitro and in vivo. The findings suggest that cantharidin is a potential agent for the treatment of TNBC.

Cantharidin, an active compound obtained from blister beetles, is a known inhibitor of PP1 and PP2A (serine/threonine protein phosphatases types 1 and type 2A) [31].It has been shown to play important roles in the regulation of cell growth [32,33], cell cycle [34-36], and cell fate determination [37]. Cantharidin exhibits strong cytotoxicity and induces apoptosis in human leukemic cells by activation of the p38 and JNK kinase pathways associated with p53 and caspase-3[9]. Cantharidin has additionally been confirmed to induce G2/M arrest and apoptosis through mitochondrial-dependent signaling pathways in bladder cancer cells [11]. Another study has shown that cantharidin induces G2/M phase arrest and apoptosis in human colorectal cancer cells through inhibition of CDK1 activity and caspase-dependent signaling pathways [12]. Therefore, the anti-tumor cytotoxicity of cantharidin has been demonstrated to be effective in various cancer cells; however, the underlying mechanisms are potentially complex and may differ according to the specific cancer. In the present study, cantharidin was found to be cytotoxic to TNBC cells, both in vitro and in vivo, and to induce cell apoptosis and inhibit cell autophagy. The attenuation of cantharidin-induced cytotoxicity by Beclin-1 suggests that the Beclin-1 pathway is involved in the inhibition of autophagy. Previous studies have indicated that the effects of cantharidin in cancer cells may involve DNA damage, cell cycle arrest, and mitochondria- or caspase-dependent apoptosis pathways and associated regulatory proteins. Therefore, more studies are needed to understand the mechanism beyond beside apoptosis and autophagy. The development of cantharidin-based therapies against TNBC requires further elucidation of these mechanisms.

The present immunofluorescence data show that cantharidin inhibits autophagosome formation. The immunoblotting results further indicate that cantharidin suppressed both the conversion of LC3 I to LC3 II and Beclin-1 expression. Beclin-1 overexpression attenuated cantharidin-induced inhibition of cell proliferation inhibition. Autophagy is a homeostatic process involving the degradation of cellular proteins and damaged, obsolete organelles [38]; these proteins and organelles are engulfed by autophagosomes, digested in lysosomes, and recycled to sustain protein homeostasis, cellular metabolism, and cell self-renewal [39]. Autophagy has dual roles in cancer as both a tumor suppressor and tumor promoter [40]. The inhibition of pro-survival autophagy has been shown to trigger apoptotic cell death and kill cancer cells [28, 41-43]; furthermore, in preclinical models, the administration of autophagy inhibitors in combination with chemotherapy induced cancer cell death and inhibited cell growth to a greater extent than chemotherapy alone [44]. Our study has confirmed that cantharidin, when administered alone, was able to inhibit autophagy in TNBC cells and cantharidin could be considered as a potential treatment agent for TNBC. While 
the administration of cantharidin combined with autophagy inhibitors, such as chloroquine or hydroxychloroguine [41], may enhance anti-tumor cytotoxicity and exerts stronger cell proliferation-inhibiting effects, which needs further study.

TNBC is characterized by the lack of estrogen, progesterone, and epidermal growth factor receptors, which makes this cancer resistant to existing endocrine therapies and targeted therapies. Therefore, novel therapeutic strategies against TNBC are urgently needed. Cantharidin and its derivative norcantharidin have both been demonstrated to induce cell apoptosis and inhibit cell growth, adhesion, and migration in human breast cancer cells [18]. Cantharidin additionally exerts potent anti-tumor effects. We only treated the TNBC cells with cantharidin resulting in cancer cells proliferation inhibition. Several studied aimed at the development of synthetic cantharidin analogues with strong anti-tumor ability and fewer side effects have been reported [45]. In addition, the development of safer and more effective cantharidin derivatives may be considered as a strategy for the treatment of TNBC. Recent studies showed that thiostrepton [1] and bicalutamide [2] may also be potential therapeutic approach, which can be developed as promising combination therapeutic strategies for treating TNBC patients.

\section{Acknowledgements}

This work was supported by Shanghai "Integrated Traditional Chinese and Western Medicine" program (ZY3-RCPY-4-2027), Innovation Team of Shanghai Traditional Chinese Medicine, Training Scheme of Back-up Experts of Shanghai University of Traditional Chinese Medicine, Putuo District Science and Technology Commission research project (No. 2011PTKW007) and Key Medical Discipline Project of Shanghai Putuo Distinct.

\section{Disclosure Statement}

The authors declare that they have no conflict of interest. All applicable international, national, and/or institutional guidelines for the care and use of animals were followed.

\section{References}

1 Jemal A, Bray F, Center MM, Ferlay J, Ward E, Forman D: Global cancer statistics. CA Cancer J Clin 2011;61:69-90.

-2 Perou CM, Sorlie T, Eisen MB, van de Rijn M, Jeffrey SS, Rees CA, Pollack JR, Ross DT, Johnsen H, Akslen LA, Fluge O, Pergamenschikov A, Williams C, Zhu SX, Lonning PE, Borresen-Dale AL, Brown PO, Botstein D: Molecular portraits of human breast tumours. Nature 2000;406:747-752.

3 Brenton JD, Carey LA, Ahmed AA, Caldas C: Molecular classification and molecular forecasting of breast cancer: ready for clinical application? J Clin Oncol 2005;23:7350-7360.

-4 Cleator S, Heller W, Coombes RC: Triple-negative breast cancer: therapeutic options. Lancet Oncol 2007;8:235-244.

5 Foulkes WD, Smith IE, Reis-Filho JS: Triple-negative breast cancer. N Engl J Med 2010;363:1938-1948.

6 Dorn DC, Kou CA, Png KJ, Moore MA: The effect of cantharidins on leukemic stem cells. Int J Cancer 2009;124:2186-2199.

7 Nickolls LC, Teare D: Poisoning by cantharidin. Br Med J 1954;2:1384-1386.

-8 Yi SN, Wass J, Vincent P, Iland H: Inhibitory effect of norcantharidin on K562 human myeloid leukemia cells in vitro. Leuk Res 1991;15:883-886.

-9 Huh JE, Kang KS, Chae C, Kim HM, Ahn KS, Kim SH: Roles of p38 and JNK mitogen-activated protein kinase pathways during cantharidin-induced apoptosis in U937 cells. Biochem Pharmacol 2004;67:1811-1818.

10 Huan SK, Lee HH, Liu DZ, Wu CC, Wang CC: Cantharidin-induced cytotoxicity and cyclooxygenase 2 expression in human bladder carcinoma cell line. Toxicology 2006;223:136-143. 


\section{Cellular Physiology Cell Physiol Biochem 2017;43:1829-1840 \\ \begin{tabular}{l|l|l} 
DOI: 10.1159/000484069 & $\begin{array}{l}\text { O 2017 The Author(s). Published by S. Karger AG, Basel } \\
\text { www.karger.com/cpb }\end{array}$ \\
\hline
\end{tabular}}

Li et al.: Cantharidin Inhibits the Growth of TNBC Cells

11 Kuo JH, Chu YL, Yang JS, Lin JP, Lai KC, Kuo HM, Hsia TC, Chung JG: Cantharidin induces apoptosis in human bladder cancer TSGH 8301 cells through mitochondria-dependent signal pathways. Int J Oncol 2010;37:1243-1250.

12 Huang WW, Ko SW, Tsai HY, Chung JG, Chiang JH, Chen KT, Chen YC, Chen HY, Chen YF, Yang JS: Cantharidin induces G2/M phase arrest and apoptosis in human colorectal cancer colo 205 cells through inhibition of CDK1 activity and caspase-dependent signaling pathways. Int J Oncol 2011;38:1067-1073.

13 Li W, Xie L, Chen Z, Zhu Y, Sun Y, Miao Y, Xu Z, Han X: Cantharidin, a potent and selective PP2A inhibitor, induces an oxidative stress-independent growth inhibition of pancreatic cancer cells through G2/M cellcycle arrest and apoptosis. Cancer Sci 2010;101:1226-1233.

14 Chen YN, Chen JC, Yin SC, Wang GS, Tsauer W, Hsu SF, Hsu SL: Effector mechanisms of norcantharidininduced mitotic arrest and apoptosis in human hepatoma cells. Int J Cancer 2002;100:158-165.

15 Yeh CB, Su CJ, Hwang JM, Chou MC: Therapeutic effects of cantharidin analogues without bridging ether oxygen on human hepatocellular carcinoma cells. Eur J Med Chem 2010;45:3981-3985.

16 Kok SH, Cheng SJ, Hong CY, Lee JJ, Lin SK, Kuo YS, Chiang CP, Kuo MY: Norcantharidin-induced apoptosis in oral cancer cells is associated with an increase of proapoptotic to antiapoptotic protein ratio. Cancer Lett 2005;217:43-52.

17 Williams LA, Moller W, Merisor E, Kraus W, Rosner H: In vitro anti-proliferation/cytotoxic activity of cantharidin (Spanish Fly) and related derivatives. West Indian Med J 2003;52:10-13.

18 Shou LM, Zhang QY, Li W, Xie X, Chen K, Lian L, Li ZY, Gong FR, Dai KS, Mao YX, Tao M: Cantharidin and norcantharidin inhibit the ability of MCF-7 cells to adhere to platelets via protein kinase $\mathrm{C}$ pathwaydependent downregulation of alpha2 integrin. Oncol Rep 2013;30:1059-1066.

19 Eum KH, Lee M: Crosstalk between autophagy and apoptosis in the regulation of paclitaxel-induced cell death in v-Ha-ras-transformed fibroblasts. Mol Cell Biochem 2011;348:61-68.

-20 Ouyang L, Shi Z, Zhao S, Wang FT, Zhou TT, Liu B, Bao JK: Programmed cell death pathways in cancer: a review of apoptosis, autophagy and programmed necrosis. Cell Prolif 2012;45:487-498.

21 Moubarak RS, Yuste VJ, Artus C, Bouharrour A, Greer PA, Menissier-de Murcia J, Susin SA: Sequential activation of poly(ADP-ribose) polymerase 1, calpains, and Bax is essential in apoptosis-inducing factormediated programmed necrosis. Mol Cell Biol 2007;27:4844-4862.

22 Llambi F, Green DR: Apoptosis and oncogenesis: give and take in the BCL-2 family. Curr Opin Genet Dev 2011;21:12-20

23 Kelly PN, Strasser A: The role of Bcl-2 and its pro-survival relatives in tumourigenesis and cancer therapy. Cell Death Differ 2011;18:1414-1424.

24 Hassa PO: The molecular "Jekyll and Hyde" duality of PARP1 in cell death and cell survival. Front Biosci (Landmark Ed) 2009;14:72-111.

25 Mannick JB, Hausladen A, Liu L, Hess DT, Zeng M, Miao QX, Kane LS, Gow AJ, Stamler JS: Fas-induced caspase denitrosylation. Science 1999;284:651-654.

26 Leist M, Jaattela M: Four deaths and a funeral: from caspases to alternative mechanisms. Nat Rev Mol Cell Biol 2001;2:589-598.

-27 Wen X, Lin ZQ Liu B, Wei YQ: Caspase-mediated programmed cell death pathways as potential therapeutic targets in cancer. Cell Prolif 2012;45:217-224.

28 Liang C, Feng P, Ku B, Dotan I, Canaani D, Oh BH, Jung JU: Autophagic and tumour suppressor activity of a novel Beclin1-binding protein UVRAG. Nat Cell Biol 2006;8:688-699.

29 He C, Levine B: The Beclin 1 interactome. Curr Opin Cell Biol 2010;22:140-149.

-30 Mizushima N, Ohsumi Y, Yoshimori T: Autophagosome formation in mammalian cells. Cell Struct Funct 2002;27:421-429.

31 Honkanen RE: Cantharidin, another natural toxin that inhibits the activity of serine/threonine protein phosphatases types 1 and 2A. FEBS Lett 1993;330:283-286.

32 Sontag E, Fedorov S, Kamibayashi C, Robbins D, Cobb M, Mumby M: The interaction of SV40 small tumor antigen with protein phosphatase $2 \mathrm{~A}$ stimulates the map kinase pathway and induces cell proliferation. Cell 1993;75:887-897.

33 Janssens V, Goris J: Protein phosphatase 2A: a highly regulated family of serine/threonine phosphatases implicated in cell growth and signalling. Biochem J 2001;353:417-439. 


\section{Cellular Physiology Cell Physiol Biochem 2017;43:1829-1840 and Biochemistry \begin{tabular}{l|l} 
DOI: 10.1159/000484069 & $\begin{array}{l}\text { O 2017 The Author(s). Published by S. Karger AG, Basel } \\
\text { www.karger.com/cpb }\end{array}$ \\
\cline { 2 - 3 }
\end{tabular} \\ Li et al.: Cantharidin Inhibits the Growth of TNBC Cells}

34 Clarke PR, Hoffmann I, Draetta G, Karsenti E: Dephosphorylation of cdc25-C by a type-2A protein phosphatase: specific regulation during the cell cycle in Xenopus egg extracts. Mol Biol Cell 1993;4:397-

411.

-35 Shi Y: Serine/threonine phosphatases: mechanism through structure. Cell 2009;139:468-484.

-36 Ludlow JW, Nelson DA: Control and activity of type-1 serine/threonine protein phosphatase during the cell cycle. Semin Cancer Biol 1995;6:195-202.

-37 Mayer-Jaekel RE, Ohkura H, Gomes R, Sunkel CE, Baumgartner S, Hemmings BA, Glover DM: The 55 kd regulatory subunit of Drosophila protein phosphatase 2A is required for anaphase. Cell 1993;72:621-633.

-38 Xie Z, Klionsky DJ: Autophagosome formation: core machinery and adaptations. Nat Cell Biol 2007;9:11021109.

39 Behrends C, Sowa ME, Gygi SP, Harper JW: Network organization of the human autophagy system. Nature 2010;466:68-76.

40 Mathew R, Karantza-Wadsworth V, White E: Role of autophagy in cancer. Nat Rev Cancer 2007;7:961-967.

41 Amaravadi RK, Yu D, Lum JJ, Bui T, Christophorou MA, Evan GI, Thomas-Tikhonenko A, Thompson CB: Autophagy inhibition enhances therapy-induced apoptosis in a Myc-induced model of lymphoma. J Clin Invest 2007;117:326-336.

42 White E, DiPaola RS: The double-edged sword of autophagy modulation in cancer. Clin Cancer Res 2009;15:5308-5316.

43 Katayama M, Kawaguchi T, Berger MS, Pieper RO: DNA damaging agent-induced autophagy produces a cytoprotective adenosine triphosphate surge in malignant glioma cells. Cell Death Differ 2007;14:548-558.

44 Yang ZJ, Chee CE, Huang S, Sinicrope FA: The role of autophagy in cancer: therapeutic implications. Mol Cancer Ther 2011;10:1533-1541.

45 Kok SH, Chui CH, Lam WS, Chen J, Tang JC, Lau FY, Cheng GY, Wong RS, Chan AS: Induction of apoptosis on carcinoma cells by two synthetic cantharidin analogues. Int J Mol Med 2006;17:151-157. 